\title{
MODIFYING A THRESHER FOR ENSILING THE GREEN RICE STRAW BY SHREDDING
}

\author{
Mohamed A. Basiouny* \\ G. H. A. Ghanem**
}

ABSTRACT

A specific modification was done in this study to convert the function of the thresher to be suitable for shredding the green rice straw to be prepared after that as a silage. The indicators of shredder (modified thresher or shredding machine) performance were studied under the effect of different levels of feed rate, shredding cylinder speed, concave clearance ratio and bulk density of the shredded green rice straw. The most important results showed that at higher shredding efficiencies of green rice straw, the silage characteristic might be improved. In addition, the reduction percentage from the highest to the lowest shredding efficiency was of $3.41 \%$ and all the values were very close to each other. The lowest cost for producing of one megagram from shredded green rice straw was of 14.05LE and the consumed energy for the unit was of $5.632 \mathrm{~kW} . \mathrm{h} / \mathrm{Mg}$ at feed rate of $300 \mathrm{~kg} / \mathrm{h}$, shredding cylinder speed of $18.4 \mathrm{~m} / \mathrm{s}$ and concave clearance ratio of 1.0. During ensiling process, the bulk density of $66.5 \mathrm{~kg} / \mathrm{m}^{3}$ has achieved a preferable results for silage temperature and its quality in comparison with the two other bulk densities.

\section{INTRODUCTION}

Tn Egypt, the locally produced forage quantity is not sufficient for feeding the livestock population; the thing which led to a forage gap

in the feeding process. There is a gap between the available quantity of green forage and the required amount of animal feed. The gap between the availability and requirement of feed is wide and the estimated shortage is 3.1million tons of total digestible nutrience per year. The forage gap or the feed shortage has been partially narrowed to become 2.42 million tons because of using new forage resources (El-Shazly, 1988; Bendary et al., 1999; Eweedah, 2000; AboSalim and Bendary, 2005 and Bendray et al., 2006).

*Researcher, Ag. Eng. Res. Inst., Dokki, Giza, Egypt.

**Prof., animal production Res. Inst., Dokki, Giza, Egypt. 
Silage is the feedstuff resulting from the preservation of green forage crops by acidification. Acidification is the result of the fermentation of the forage in the absence of oxygen. There are two main phases in the ensiling process. The first is the aerobic phase which occurs in the presence of oxygen. Oxygen is present in the forage as it is placed in the silo. This oxygen is consumed by the living plant material through the process of respiration. Under aerobic conditions plant enzymes and microorganisms consume oxygen and bum up the plant water-soluble carbohydrates (sugars) producing carbon dioxide and heat. The length of this phase is variable depending on ensiling conditions; it could last for a few hours or for as long as several days. It is good silage making practice to limit this phase as much as possible since water-soluble carbohydrates are being consumed and other nutrients are being destroyed. The heat generated by an extended aerobic phase can raise the temperature of the ensiling forage material sufficiently to cause heat damage. Good silage making practices reduce the amount of time that aerobic microorganisms and oxidizing plant enzymes are able to function. This is accomplished by chopping the silage to a short length, packing it thoroughly, and sealing the silo effectively. The second or anaerobic phase begins when the available oxygen is used up through plant respiration and aerobic bacteria cease to function. Anaerobic bacteria (bacteria that grow in the absence of oxygen) then begin to multiply rapidly and the fermentation process begins (Machin, 1999; Chin, 2001 and AARD, 2007). Chopping, cutting, shredding, and bruising all improve the potential for making good silage. This is due to cell breakage which favors bacterial growth and facilitates adequate packing for air exclusion. Anaerobic conditions can be established quickly in cut forage and thus temperature rise may be limited to $25 \%$ of that observed in forages which have not been chopped. More lactic acid is formed and less dry matter losses occur when forage is chopped. The $\mathrm{pH}$ of the silage and its ammonia content that result from protein degradation are reduced, and lactic acid concentrations are increased with progressively shorter chop lengths. Where the length of cut has been reduced in silages an increased voluntary consumption by cattle has been observed (AARD, 2007 and Kawamoto et al., 2007). Temperature plays an important role in the ensilage process. High 
temperatures developing after 1 to 4 days are evidence of improper ensiling procedures. With ideal conditions of harvest and storage, the temperature should not rise above $40^{\circ} \mathrm{C}$. At temperatures above $50^{\circ} \mathrm{C}$ feed losses occur. The most frequent causes of over-heating are: 1) too low moisture content. 2) over-mature forage. 3) too long a forage cut. 4) insufficient or slow packing (Pitt, 1983; O'donnell et al., 1997; Ashbell et al., 2002 and Mills and KungJr, 2002). Recently in Egypt, grains of some new hybrid and varieties of rice crop (Sakha 101, 102 and 104) which represent about $27 \%$ of cultivated rice crop area harvested while most of its leaves and stalks are still green and have suitable moisture content for ensiling (TRRC, 2005). However, ensiling fresh green rice straw immediately after harvesting the grains is practical in animal feeding. Moreover, it may offer a significant reduction in feeding cost (Ghanem et al., 2005 and Bendray et al., 2006). Therefore, the present study aimed to modify the thresher to serve as a shredder for making silage from fresh green rice straw. Moreover, the influence of different bulk densities of silage on the silage temperature and consequently its quality was investigated.

\section{MATERIALS AND METHODS}

For achieving the objectives of the present study, some of parts of the threshing machine were modified to serve as a shredder of fresh green rice straw and setting it a deformed shape for making silage.

\section{Threshing machine:}

This type of machine was mainly designed for threshing the small areas of rice crop characterized for mini farmers. This may be due to its light mass and consequently can easily move among fields. The threshing capacity of it is about $600 \mathrm{~kg} / \mathrm{h}$. The threshing machine is consisted of the following parts: Threshing drum of spiketooth type which provided with four paddles and distributed on the circumference of threshing drum from the outlet direction to deliver the rice straw. Also the threshing drum is covered by the upper and lower concaves. The upper concave is provided with spiral louvers to direct rice straw into the outlet after threshing. But the lower concave serves as a wire mesh to facilitate the separation of rice grain after its threshing. In addition, it is provided, from the outer surface with orifice and bolts for controlling the front and rear clearances between 
it and threshing drum from the inner surface. The engineering drawing of the threshing drum is shown in Fig. 1 and a detailed description of the whole machine is illustrated in Table 1.
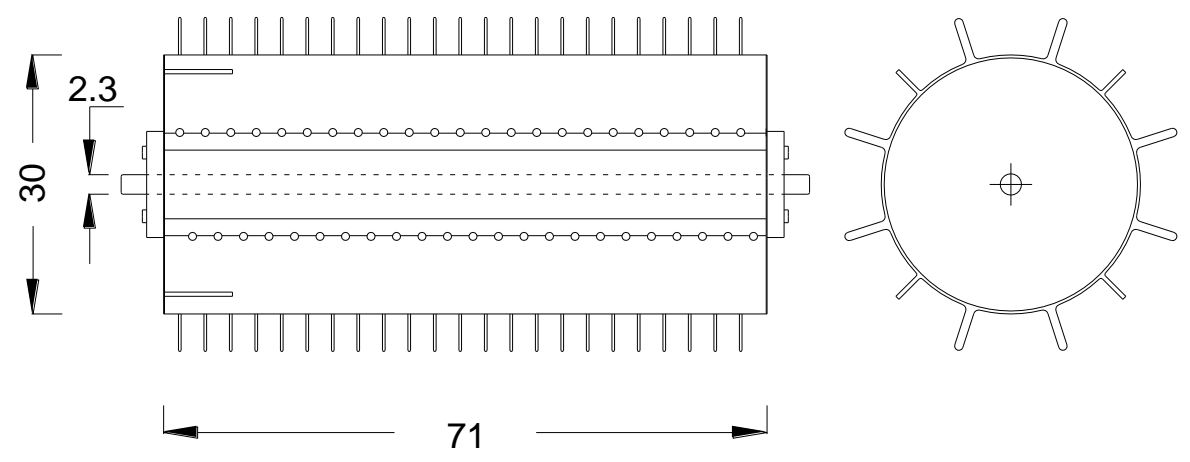

DIMENSIONS IN cm

$$
\text { ELEVATION }
$$

SIDE

Fig. 1: An engineering drawing showing the threshing drum before its modification.

Table 1: Specifications of thresher and modified thresher.

\begin{tabular}{|c|c|c|}
\hline Item & Thresher & Thresher after modification \\
\hline Function & Thresh rice & Shred green rice straw \\
\hline Manufacturer & Philippines & Philippines (except the cylinder) \\
\hline \multicolumn{3}{|l|}{ Dimensions: } \\
\hline Overall height, $\mathrm{m}$ & 1.38 & 1.38 \\
\hline Overall length, $\mathrm{m}$ & 1.08 & 1.08 \\
\hline Overall width, m & 0.80 & 0.80 \\
\hline Mass, $\mathrm{kg}$ & 105 & 112 \\
\hline \multicolumn{3}{|l|}{ Cylinder (Drum): } \\
\hline Type & Spiketooth & Knives (U-shape) \\
\hline Length, $\mathrm{cm}$ & 71 & 71 \\
\hline Diameter, $\mathrm{cm}$ & 30 & 28 \\
\hline \multicolumn{3}{|l|}{ Engine: } \\
\hline Power & $6.8 \mathrm{~kW}(5 \mathrm{hp})$ & $6.8 \mathrm{~kW}(5 \mathrm{hp})$ \\
\hline Fuel & gasoline & gasoline \\
\hline The modified part & $\begin{array}{c}\text { Threshing unit } \\
\text { (cylinder \& concave) }\end{array}$ & $\begin{array}{c}\text { Shredding unit } \\
\text { (cylinder \& concave) }\end{array}$ \\
\hline Construction & All steel & All steel \\
\hline
\end{tabular}




\section{Suggested modifications:}

The thresher drum was replaced by a special cylinder for shredding the green rice straw. Its diameter was of $28 \mathrm{~cm}$ to keep the dimensions of the thresher. The frame of shredding cylinder was manufactured by iron sheet of $1.5 \mathrm{~mm}$ thick. Shredding knives type $U$ was employed as shown in Fig. 2. To ensure the fixing of these knives on the circumference of cylinder, 15 knives were firstly fixed on equidistant on the iron slide by $4 \mathrm{~cm}$ width, $72 \mathrm{~cm}$ long and $2 \mathrm{~mm}$ thick. Six groups of knives were formed and were constructed on the cylinder by an angle $11^{\circ}$ from the longitudinal axis of cylinder to orientate the shredded rice straw to the outlet opening. Moreover, 6 paddles were distributed on the cylinder circumference from the outlet side to deliver the shredded straw out. The spiral louvers of the upper concave were cancelled. While, lower concave (wire mesh) was covered by iron sheet of $1 \mathrm{~mm}$ thick to ensure good shredding of straw and not penetrate through the wire mesh. The lower concave clearance was controlled by means of orifices and bolts Fig. 3. The machine modification was accomplished in the artificial city workshops in Kafr Elsheikh governorate. The group of experiments was carried out during the year of 2009 in the research farm and animal production research station, Sakha, Kafr El-sheikh.

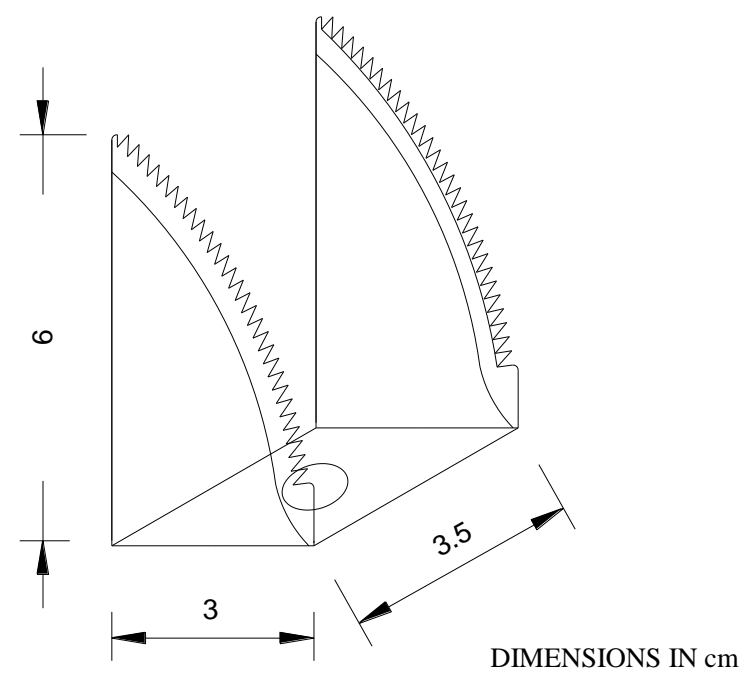

Fig. 2: Detailed description of the shredding knife. 


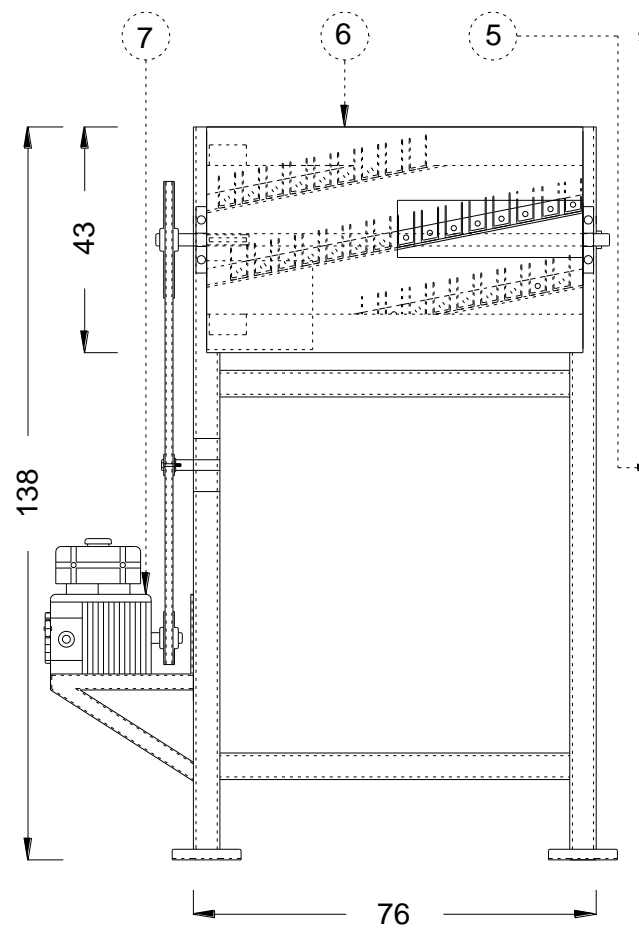

ELEVATION

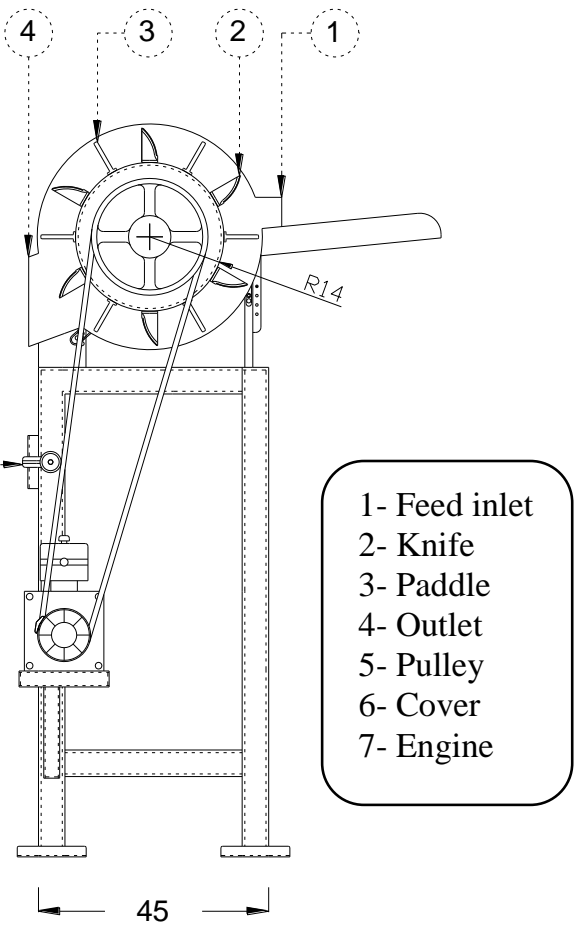

SIDE

DIMENSIONS IN cm

Fig. 3: Engineering drawing of the shredding machine used for shredding the fresh green rice straw.

\section{Fresh green rice straw:}

The utilized rice straw was of Sakha 101 which formerly harvested by the Japanese combine. For ensiling purposes, the fresh green rice straw which still has suitable moisture content was used. The dry matter (DM) represents about $34.86 \%$ from the components of rice straw and about $65.41 \%$ moisture.

\section{Studied factors of shredding machine:}

Performance description of the shredding machine was shown by studying the influence of three operating treatments as follows:

- Three feed rates of green rice straw of 200,300 and $400 \mathrm{~kg} / \mathrm{h}$.

- Three speeds of shredding cylinder of $16.28,18.41$ and $20.32 \mathrm{~m} / \mathrm{s}$.

- Three clearance ratios of the concave between the rear and front of $0.333,0.5$ and 1.0 . 
From the preliminary study, it was remarked that the lowest rear clearance permissible is about $1 \mathrm{~cm}$ and then the clearance ratios were calculated on this basis. The optimum operating conditions for shredding machine were determined regarding the percentage of unshredded green rice straw and shredding efficiency of rice straw.

\section{Silage making:}

Fresh green rice straw was taken immediately after harvesting grains and shredding it for making silage in plastic bags (30kg capacity). The shredded green rice straw was sprinkled with $50 \mathrm{~kg}$ molasses solved in 50liter of water per ton to enhance the fermentation of silage. The best treatment of the shredding machine which ensures the highest shredding efficiency and the lowest unshredded green rice straw was selected for ensiling process. The shredded green rice straw packed in plastic bags forming three densities of the shredded green rice straw of 59.5, 62.8 and $66.5 \mathrm{~kg} / \mathrm{m}^{3}$. The rice straw mass of $25 \mathrm{~kg}$ was kept constant for all the investigated treatments. During the package of green rice straw inside plastic bags, they looked like a cylinder of fixed diameter of $0.75 \mathrm{~m}$. The change in shredded rice straw volume inside plastic bags was done by hand pressure. The plastic bags were tightly sealed after inserting one thermocouple into each bag for measuring silage temperature and to get anaerobic conditions. Silage was stored for 60 days beginning from 11/10/2009. Representative samples were taken to determine silage quality. Silage $\mathrm{pH}$ directly using 680 digital $\mathrm{pH}$ meter, while lactic acid, total volatile fatty acids (TVFA's) and Ammonia Nitrogen $\left(\mathrm{NH}_{3}-\mathrm{N}\right)$ concentrations were determined according to the methods described by ACF, 1995; Warner, 1964 and Bergen et al., 1974.

\section{Measuring instruments:}

The speed of shredding cylinder was measured by a digital tachometer with rpm and after that converted to liner speed by $\mathrm{m} / \mathrm{s}$. Fuel consumption was determined using the graduated glass tumbler then energy consumption was calculated. Digital thermometer (Model: HH-26J-USA) and thermocouples were employed for measuring the silage and ambient temperatures. Both of silage and ambient temperature were recorded daily during the ensiling period at 12 Noon. 


\section{PROCEDURES:}

The percentage of unshredded green rice straw (UGRS) and shredding efficiency $\left(E_{s}\right)$ were calculated from the following equations:

$$
\begin{aligned}
& \text { UGRS, } \%=\frac{\text { Mass of unshredded green rice straw }}{\text { Tolal massof green rice straw }} \times 100 \ldots \ldots \ldots \ldots \ldots 1 \\
& E_{s}, \%=\left(1-\frac{\text { Massof unshredded green rice straw }}{\text { Tolal massof green rice straw }}\right) \times 100 \ldots \ldots \ldots \ldots . . \ldots 2
\end{aligned}
$$

\section{Unit Energy, kw.h/Mg:}

The power consumption requirements were calculated according to the formula of Hunt, 1984 as follows:

$$
\text { Power consumption, } k W=\frac{F C x \rho_{f} \times L C V \times 427 \times \eta_{m} \times \eta_{t h}}{3600 \times 75 \times 1.36} \ldots \ldots \ldots . .3
$$

Where;

$F C$ is the fuel consumption, $\ell / \mathrm{h}$;

$\rho_{f} \quad$ is the fuel density, $\mathrm{kg} / \ell$ (for gasoline $=0.72$ );

$L C V$ is the lower calorific value of fuel $(11000 \mathrm{kcal} / \mathrm{kg})$;

427 is the thermo-mechanical equivalent, $\mathrm{kg} . \mathrm{m} / \mathrm{kcal}$;

$\eta_{m} \quad$ is the engine mechanical efficiency, (for Otto engine $=85 \%$ ) and

$\eta_{t h} \quad$ is the engine thermal efficiency, (for Otto engine $=25 \%$ ).

Then, the unit energy requirements can be calculated as follows:

Unit energy, $k W . h / M g=\frac{\text { Power consumption }(k W)}{\text { Pr oductivity, } M g / h} \ldots \ldots \ldots \ldots \ldots \ldots . . \ldots 4$

\section{Total cost, LE/h:}

Total cost requirements of the shredding machine include fixed and operating costs. Declining balance method was used to determine the depreciation (Hunt, 1983). The unit operating cost could be estimated from the following formula:

Unit operating cost,$L E / M g=\frac{\text { Shredder cost }, L E / h}{\text { Productivity }, M g / h} \ldots \ldots \ldots \ldots \ldots . . . .5$ 


\section{RESULTS AND DISCUSSION}

\section{UNSHREDDING PERCENTAGE OF GREEN RICE STRAW:}

Fig. 4 shows the effect of cylinder speed and feed rate on the unshredding percentage of green rice straw at three different concave clearance ratios. From the figure, it can be generalized that trend of the unshredding percentage of green rice straw decreased by increasing the concave clearance ratio. At feed rate of $200 \mathrm{~kg} / \mathrm{h}$ and cylinder speed of $16.28 \mathrm{~m} / \mathrm{s}$, the unshredding percentage of green rice straw decreased from 4.47 to $3.53 \%$ when the concave clearance ratio was increased from 0.333 to 1.0 . At cylinder speed of $20.32 \mathrm{~m} / \mathrm{s}$ and clearance ratio of 1.0 , the unshredding percentage of green rice straw increased from 3.22 to $3.66 \%$ when the feed rate increased from 200 to $400 \mathrm{~kg} / \mathrm{h}$. Briefly, it was noticed that the highest value of unshredding percentage of green rice straw was found $5.11 \%$ at the conditions of $400 \mathrm{~kg} / \mathrm{h}$ feed rate. $16.28 \mathrm{~m} / \mathrm{s}$ cylinder speed and 0.333 concave clearance ratio. On the other hand, the lowest value of unshredding percentage of green rice straw was found $1.76 \%$ at the conditions of $300 \mathrm{~kg} / \mathrm{h}, 18.41 \mathrm{~m} / \mathrm{s}$ cylinder speed and 1.0 concave clearance ratio. It seems that the increase percentage from the lowest to the highest value of $190.34 \%$.

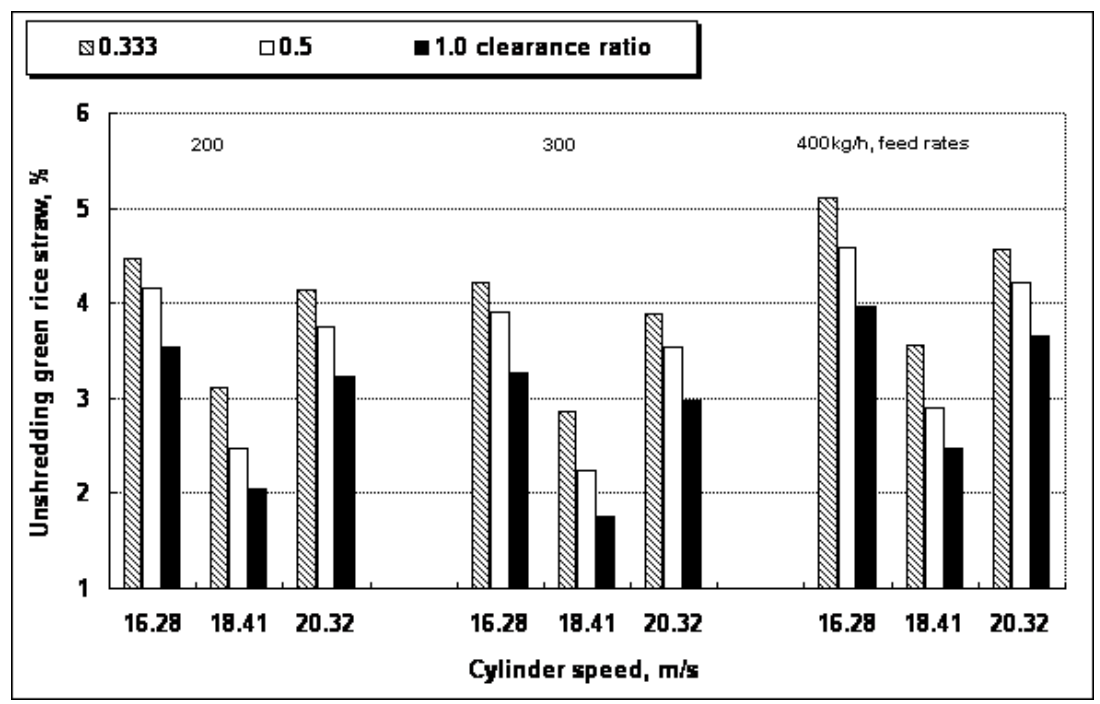

Fig. 4: The effect of cylinder speed and feed rate on the unshredded green rice straw at three different concave clearance ratios. 


\section{SHREDDING EFFICIENCY OF GREEN RICE STRAW:}

Fig. 5 shows the influence of cylinder speed and feed rate on the shredding efficiency at three different concave clearance ratios. As a general trend, the shredding efficiency increased by increasing the concave clearance ratio at constant feed rate and cylinder speed. At feed rate of $200 \mathrm{~kg} / \mathrm{h}$ and cylinder speed of $16.28 \mathrm{~m} / \mathrm{s}$, the shredding efficiency increased from 95.53 to $96.47 \%$ when the concave clearance ratio increased from 0.333 to 1.0 . At $18.41 \mathrm{~m} / \mathrm{s}$ cylinder speed and 0.5 concave clearance ratio, the shredding efficiency of green rice straw was decreased from 97.53 to $97.11 \%$ when the feed rate increased from 200 to $400 \mathrm{~kg} / \mathrm{h}$. At $400 \mathrm{~kg} / \mathrm{h}$ feed rate and 0.5 concave clearance ratio, the shredding efficiency of GRS was increased from 95.41 to $95.79 \%$ when the cylinder speed increased from 16.28 to $20.32 \mathrm{~m} / \mathrm{s}$. The highest shredding efficiency of green rice straw of $98.24 \%$ was found at 1.0 concave clearance ratio, $18.41 \mathrm{~m} / \mathrm{s}$ cylinder speed and $300 \mathrm{~kg} / \mathrm{h}$ feed rate. In the opposite side, the lowest one was of $94.89 \%$ and obtained at 0.333 concave clearance ratio, $16.28 \mathrm{~m} / \mathrm{s}$ cylinder speed and $400 \mathrm{~kg} / \mathrm{h}$ feed rate. The reduction percentage from the highest to the lowest value of shredding efficiency was of $3.41 \%$. It can be concluded that, the highest values of the shredding efficiency of green rice straw might be give a good silage characteristics when ensiling and this in accordance with AARD, 2007 and Kawamoto et al., 2007.

\section{REQUIRED ENERGY OF THE SHREDDING MACHINE:}

Fig. 6 illustrates the relationship between cylinder speed and unit energy at different levels of feed rate and concave clearance ratio. As shown in the figure, the unit energy increased approximately linearly as feed rate, cylinder speed and concave clearance ratio were increased. For example, at $16.28 \mathrm{~m} / \mathrm{s}$ cylinder speed and 1.0 concave clearance ratio, the unit energy increased from 1.607 to $6.325 \mathrm{~kW} . \mathrm{h} / \mathrm{Mg}$ as the feed rate increased from 200 to $400 \mathrm{~kg} / \mathrm{h}$. From another side, at $300 \mathrm{~kg} / \mathrm{h}$ feed rate and 0.333 clearance ratio, when the cylinder speed increased from 16.28 to $20.32 \mathrm{~m} / \mathrm{s}$, the unit energy increased from 3.758 to $6.173 \mathrm{~kW} \cdot \mathrm{h} / \mathrm{Mg}$. At $18.41 \mathrm{~m} / \mathrm{s}$ cylinder speed and 1.0 concave clearance ratio, the unit energy increased from 5.632 to $6.947 \mathrm{~kW} . \mathrm{h} / \mathrm{Mg}$ as the feed rate increased from 300 to $400 \mathrm{~kg} / \mathrm{h}$. As a conclusion, the lowest values of unit energy were 
obtained at $200 \mathrm{~kg} / \mathrm{h}$ feed rate and $16.28 \mathrm{~m} / \mathrm{s}$ cylinder speed for the three levels of concave clearance ratio. But the highest ones were achieved at $400 \mathrm{~kg} / \mathrm{h}$ feed rate and $20.32 \mathrm{~m} / \mathrm{s}$ cylinder speed for the same clearance ratios.

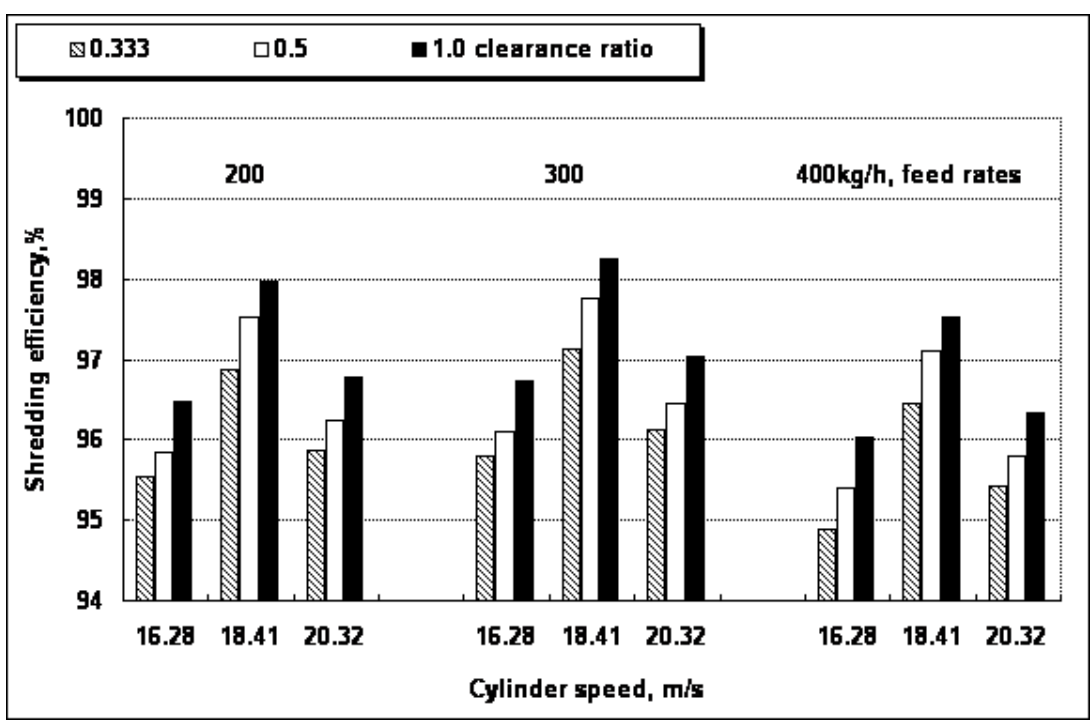

Fig. 5: The influence of cylinder speed and feed rate on the shredding efficiency at three different concave clearance ratios.

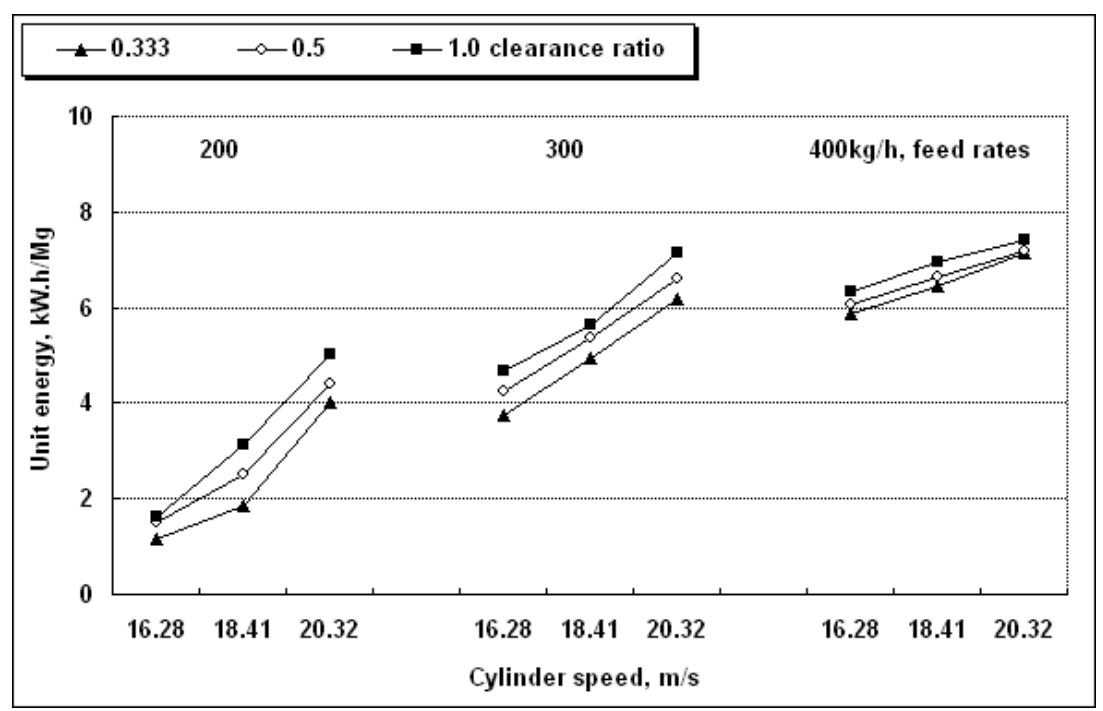

Fig. 6: Relationship between cylinder speed and unit energy at different levels of feed rate and concave clearance ratio. 


\section{OPERATING COST OF THE SHREDDING MACHINE:}

Fig. 7 explains the unit operating cost as affected by cylinder speed at different levels of feed rate and concave clearance ratio. As illustrated in the shown histograms, the unit operating cost was slightly decreased as the concave clearance ratio increased when both of the feed rate and cylinder speed were fixed. All the values of the unit operating cost were nearly close to each other at all the investigated variables. The feed rate of $200 \mathrm{~kg} / \mathrm{h}$ has achieved the highest values of unit operating cost, while the $400 \mathrm{~kg} / \mathrm{h}$ has achieved the lowest values of unit operating cost under all the other investigated variables. At feed rate of $300 \mathrm{~kg} / \mathrm{h}$ and cylinder speed of $18.41 \mathrm{~m} / \mathrm{s}$, the unit operating cost decreased from 14.21 to 14.05LE/Mg when the concave clearance ratio increased from 0.333 to 1.0. From the histogram, it can be stated that the highest unit operating cost was obtained at $200 \mathrm{~kg} / \mathrm{h}$ feed rate, $16.28 \mathrm{~m} / \mathrm{s}$ cylinder speed and 0.333 concave clearance ratio and the lowest one was given at $400 \mathrm{~kg} / \mathrm{h}$, $18.41 \mathrm{~m} / \mathrm{s}$ and 1.0 concave clearance ratio. Estimation of the annual global cost for the shredding machine was listed in the Table 2. From the Table 2 , it can be noticed that the estimated operating cost of shredder was of 1510LE/year. The annual global cost was of 1655.92LE/year. Whilst, the hourly shredder cost was estimated as 4.14LE.

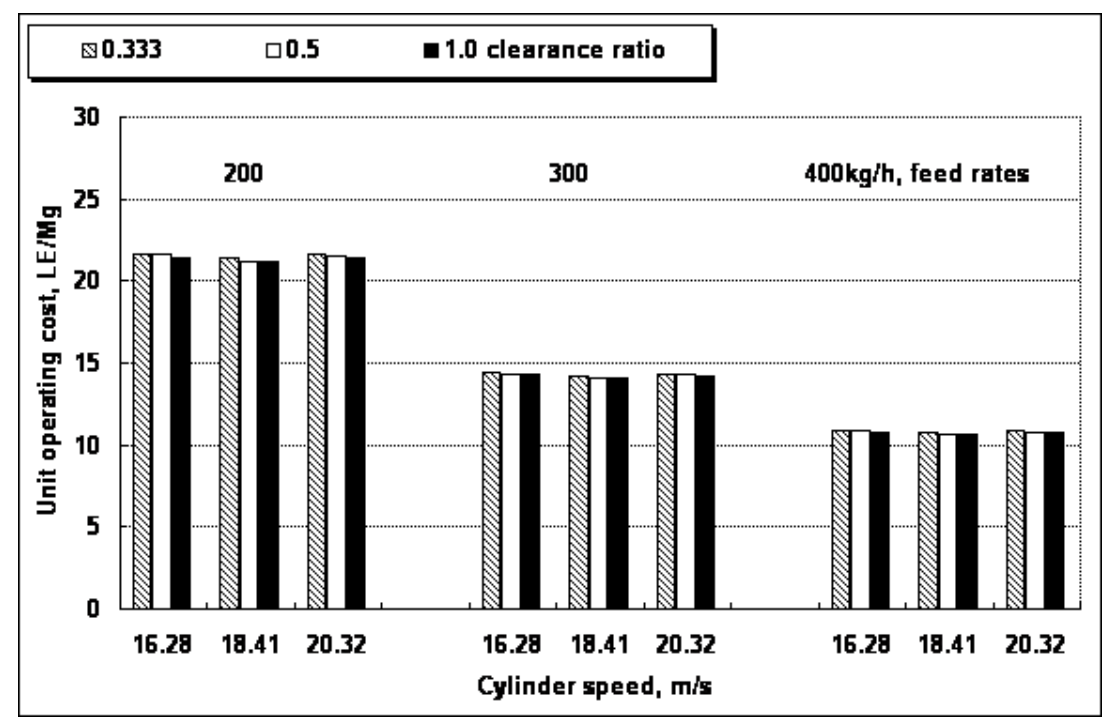

Fig. 7: Unit operating cost as affected by cylinder speed at different levels of feed rate and concave clearance ratio. 
Table 2: Estimation of the annual global cost for the shredding machine.

\begin{tabular}{|l|c|}
\hline No. of years (used before) & 9 \\
\hline Remaining value, LE & 492.19 \\
\hline Fixed cost, LE/year: & 86.86 \\
\hline a) Depreciation & 59.06 \\
b) Interest on investment, taxes, insurance and shelter & $\mathbf{1 4 5 . 9 2}$ \\
\hline The fixed cost, LE/year & 400 \\
\hline Operating hours/year & \\
\hline Operating cost, LE/year: & 100 \\
\hline a) Repairs and maintenance & 410 \\
b) Fuel + lubrication & 1000 \\
c) Labor & $\mathbf{1 5 1 0}$ \\
\hline The operating cost, LE/year & 1655.92 \\
\hline Shredder cost, LE/year & $\mathbf{4 . 1 4}$ \\
\hline Shredder cost, LE/h & \\
\hline
\end{tabular}

\section{SILAGE TEMPERATURE DURING ENSILING PROCESS:}

Fig. 8 shows the relationship between the silage and ambient temperatures and the ensiling period at three different bulk densities. AS illustrated in the curves of Fig. 8, the lowest silage temperature of $35.2^{\circ} \mathrm{C}$ was monitored after two days (48hours) from the beginning of ensiling period for highest bulk density of $66.5 \mathrm{~kg} / \mathrm{m}^{3}$. At the end of ensiling period (60days), the silage temperature reached its minimum value of $25.1^{\circ} \mathrm{C}$ and consequently the difference between it and ambient temperature was them $2.2^{\circ} \mathrm{C}$. In addition, the bulk density of $66.5 \mathrm{~kg} / \mathrm{m}^{3}$ has achieved the lowest average of silage temperature and its standard deviation of $29.31^{\circ} \mathrm{C}$ and $2.54^{\circ} \mathrm{C}$ respectively at the end of ensiling period. From the analysis of Fig. 8 , it can be concluded that this bulk density of shredded green rice straw of $66.5 \mathrm{~kg} / \mathrm{m}^{3}$ gave the silage temperature which ensure a satisfactory characteristics for the finished silage according to Pitt, 1983; O'donnell et al., 1997; Ashbell et al., 2002 and Mills and KungJr, 2002. On the opposite side, the bulk density of $59.5 \mathrm{~kg} / \mathrm{m}^{3}$ achieved the highest temperature of silage of $41.2^{\circ} \mathrm{C}$ after four days from the starting point of ensilage. While the silage temperature, at this bulk density, reached its maximum value of $27.4^{\circ} \mathrm{C}$ at the end of ensiling period and consequently 
the difference between it and ambient temperature increased to be $4.5^{\circ} \mathrm{C}$. The bulk density of $59.5 \mathrm{~kg} / \mathrm{m}^{3}$ has recorded the highest average of silage temperature and its standard deviation of $33.28^{\circ} \mathrm{C}$ and $3.98^{\circ} \mathrm{C}$ respectively after 60 days (the end of ensiling period). Moreover, the bulk density of $62.8 \mathrm{~kg} / \mathrm{m}^{3}$ achieved a silage temperature of $36.9^{\circ} \mathrm{C}$ after three days (72hours) from the starting point of ensilage. With elapsing the time, the silage temperature reached its moderate value of $26.1^{\circ} \mathrm{C}$ at the end of ensiling period and achieved an increase of $3.2^{\circ} \mathrm{C}$ above the ambient temperature. The average of silage temperature and its standard deviation, at the bulk density of $62.8 \mathrm{~kg} / \mathrm{m}^{3}$ were of $30.71^{\circ} \mathrm{C}$ and $2.56^{\circ} \mathrm{C}$ respectively at the end of ensiling period (60days).

\section{Fermentation characteristics (silage quality):}

As listed in Table 3, the bulk density of $66.5 \mathrm{~kg} / \mathrm{m}^{3}$ shredded rice straw silage assured the best results of fermented silage according to McDonald et al., 1995. Since, it gave a pH value of 3.98 and lactic acid of $5.13 \%$ (on $\mathrm{DM}$ basis). On the other hand, the lowest values of such indicators were observed at the bulk density of $59.5 \mathrm{~kg} / \mathrm{m}^{3}$. The values of DM of silage were of $32.56,31.96$ and $31.76 \%$ at bulk densities of $66.5,62.8$ and $59.5 \mathrm{~kg} / \mathrm{m}^{3}$ respectively.

Table 3: Fermentation characteristics of fresh shredded rice straw at different levels from bulk density.

\begin{tabular}{|l|c|c|c|}
\hline \multirow{2}{*}{ Items } & \multicolumn{3}{|c|}{$\begin{array}{c}\text { Bulk density of the shredded rice straw } \\
\text { silage, } \mathrm{kg} / \mathrm{m}^{3}\end{array}$} \\
\cline { 2 - 4 } & $\mathbf{6 6 . 5}$ & $\mathbf{6 2 . 8}$ & $\mathbf{5 9 . 5}$ \\
\hline $\mathrm{pH}$ & 3.98 & 4.19 & 4.27 \\
\hline Total organic acids of DM, \% & 6.90 & 6.60 & 6.20 \\
\hline Lactic acid of DM, \% & 5.13 & 4.37 & 4.22 \\
\hline TVFA's of DM, \% & 2.57 & 2.62 & 2.64 \\
\hline $\mathrm{NH}_{3}-\mathrm{N}$ of DM, \% & 0.29 & 0.27 & 0.26 \\
\hline $\mathrm{NH}_{3}-\mathrm{N}$ of total-N, \% & 4.18 & 4.16 & 4.15 \\
\hline
\end{tabular}


FARM MACHINERY AND POWER
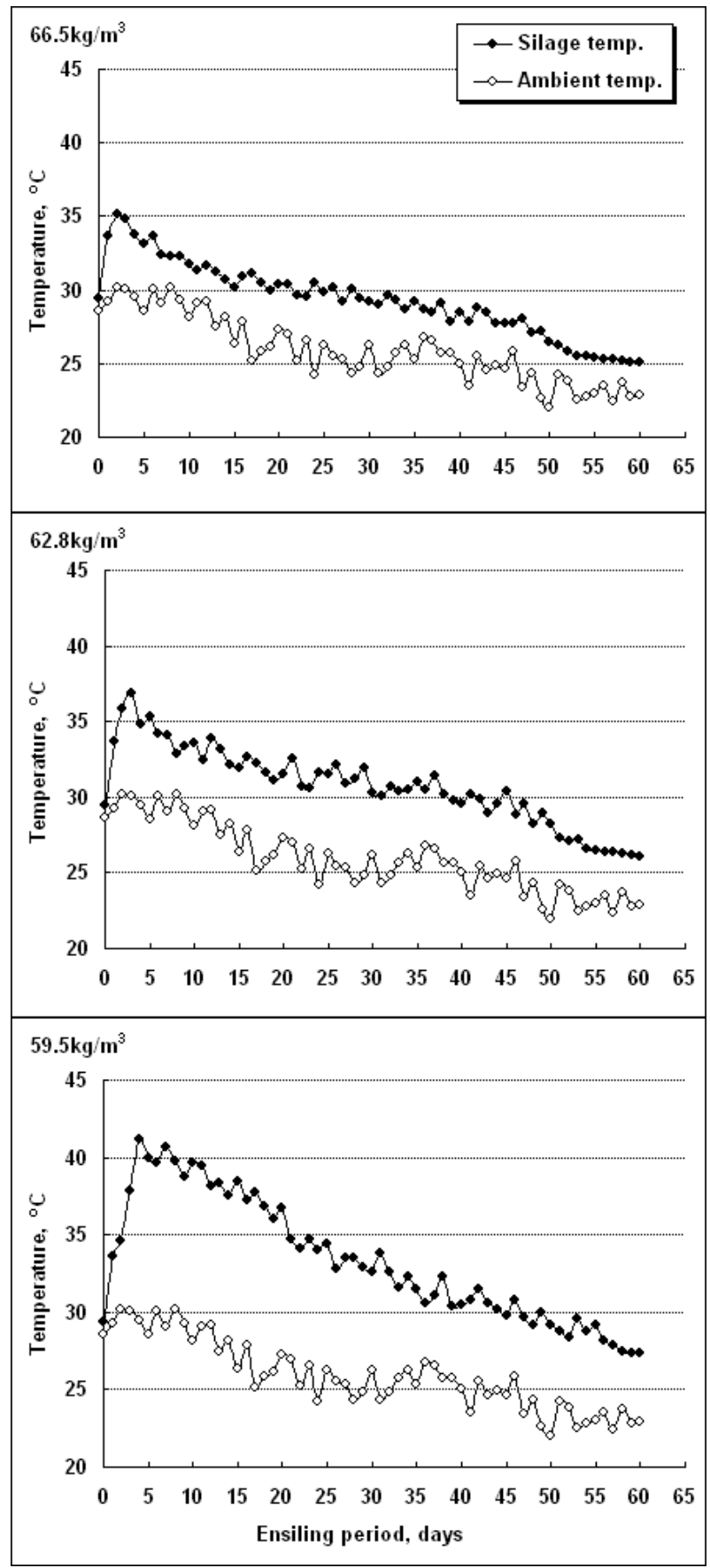

Fig. 8: Relationship between the silage and ambient temperatures and the ensiling period at three different bulk densities. 


\section{CONCLUSIONS}

The most important point from the present research could be summarized as follows:

- The highest shredding efficiency of green rice straw was of $98.24 \%$ and the lowest unshredded rice straw was of $1.76 \%$ at feed rate of $300 \mathrm{~kg} / \mathrm{h}$, shredding cylinder speed of $18.4 \mathrm{~m} / \mathrm{s}$ and concave clearance ratio of 1.0 .

- The lowest cost for producing of one megagram from shredded green rice straw was of 14.05LE and the consumed energy for the unit was of $5.632 \mathrm{~kW} . \mathrm{h} / \mathrm{Mg}$ at $300 \mathrm{~kg} / \mathrm{h}, 18.4 \mathrm{~m} / \mathrm{s}$ and 1.0 operating conditions.

- The lowest increase in silage temperature of shredded green rice straw was of $35.2^{\circ} \mathrm{C}$ after about forty eight hours from the starting point of package at bulk density of $66.5 \mathrm{~kg} / \mathrm{m}^{3}$ rice straw silage. While, at $59.5 \mathrm{~kg} / \mathrm{m}^{3}$ bulk density, the silage temperature recorded the highest increase of $41.2^{\circ} \mathrm{C}$ after four days from package.

- The lowest difference between both of ambient and rice straw silage temperature was of $2.2^{\circ} \mathrm{C}$ at silage bulk density of $66.5 \mathrm{~kg} / \mathrm{m}^{3}$.

- The bulk density of $66.5 \mathrm{~kg} / \mathrm{m}^{3}$ achieved the best characteristics of shredded straw rice silage in comparison with the investigated ones.

\section{REFERENCES}

AARD (2007). Ensiling Process. Alberta Agriculture and Rural Development (AARD), from http://www1.agric.gov.ab.ca, (Received on 26/3/2009).

AboSalim, I. A. and M. M. Bendary (2005). Forage supplies in Egyptresources-maximizing its utilization. Proc. $2^{\text {nd }}$ Conf. Anim. Prod. Res. Inst., Sakha 27-29, Sep., 2005: 57-67.

ACF (1995). Analytical Chemistry of Food. Published by Blockie Academic Professional, an imprint of Chapman and Hall, Western Cleddens Road, Bishoporiggs, Glasgow G642N, UK.

Ashbell, G.; Z. G. Weinberg; Y. Hen and I. Filya (2002). The effects of temperature on the aerobic stability of wheat and corn silages. J. Ind. Microbiol. Biotechnol. 28: 261-263.

Bendary, M. M; M. M. Mohamed and M. M. Sayeda Ahmed (1999). Nutritional studies on using sugar beet tops in animal feeding 
(performance of growing calves fed dried sugar beet tops and its silage). Egyptian J. Nutrition and feeds, Issuc., 2:167-177.

Bendray, M. M.; G. H. A. Ghanem and H. M. A. Gaafar (2006). Utilization of rice straw for feeding ruminants: (Productive performance of lactating buffaloes fed rice straw silage). J. Agric. Sci. Mansoura Univ., 31(8): 5025-5038.

Bergen, W. G.; E. H. Cach and H. E. Henderson (1974). Changes in nitrogenous compounds of the whole corn plant during ensiling and subsequent effects on dry matter intake by sheep. J. Anim. Sci., 39: 629.

Chin, F. Y. (2001). Silage production and techniques in Malaysia. $7^{\text {th }}$ Meet. Workshop FAO RWG on Grazing and Feed Resources for S.E. Asia. Manado, Indonesia.

El-Shazly, K. (1988). Nitrogen utilization by ruminant animals. World review and Dietetics, 55: 210, Fac. of Agric., Alex. Univ., Egypt.

Eweedah, N. M. (2000). Utilization of sugar beet by-products in feeding ruminants. J. Agric. Res., Tanta Univ., 26(2):145-153.

Ghanem, G. H. A.; M. M. Bendray; H. M. A. Gaafar; M. I. Abou Youssef and A. E. Deraz (2005). Utilization of rice straw for feeding ruminants: (Productive performance of lactating cows fed berseem and different from of rice straw). Animal Production Research institute $2^{\text {nd }}$ conference and Regional Symposium on Buffalo Production, 27-29 September, Sakha, Kafr El-Sheikh, Egypt, 155.

Hunt, D. (1983). Farm power and machinery management. 8th Ed. Iowa State Univ. Press, Ames., U.S.A., 59-71.

Hunt, D. (1984) Farm power and machinery management. 8th Ed. Iowa state Univ., Press Ames, U.S.A., 364-368.

Kawamoto, H.; R. Otani; A. Oshibe; H. Yamaguchi; S. Deguchi, O. Tanaka, S. Uozumi and H. Watanabe (2007). Ensilage of wilted whole crop rice (Oryza sativa L.) using a roll baler for chopped material: Silage quality in long-term storage. Japanese Society of Grassland Science, 53(2): 85-90. 
Machin, D. H. (1999). The potential use of tropical silage for livestock production, with special reference to smallholders. Proc. FAO eConf. on Trop. Silage. FAO Plant Production and Protection Paper 161. Rome., 71-78.

McDonald, P.; R. A. Edwards; J. F. D. Greenhalgh and C. A. Morgan (1995). Animal Nutrition. $5^{\text {th }}$ Ed., Copyright licensing LTD., London.

Mills, J. A. and L. KungJr (2002). The effect of delayed ensiling and application of a propionic acid-based additive on the fermentation of barley silage. J. Dairy Sci., 85: 1969-1975.

O'donnell, C.; A. G. WILLIAMS and A. J. BIDDLESTONE (1997). The effects of temperature on the effluent production potential of grass silage. Grass and Forage Science, 52: 143-349.

Pitt, R. E. (1983). Mathematical prediction of density and temperature of ensiled forage. Trans. of the ASAE, 26: 1522-1527,1532.

TRRC (2005). Technical recommendation of rice crop, Rice Sector, Agricultural Research Center, Ministry of Agriculture (In Arabic).

Warner, A. C. I. (1964). Production of volatile fatty acids in the rumen, method of measurements. Nut. Abst. And Rev., 34: 339.

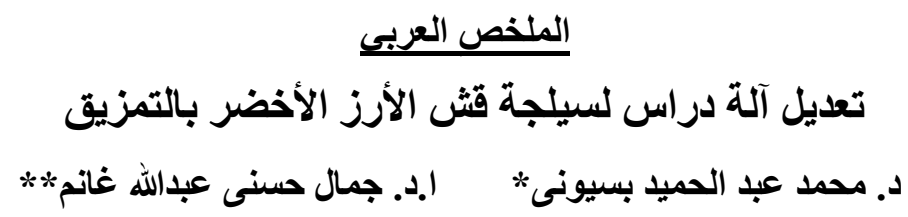

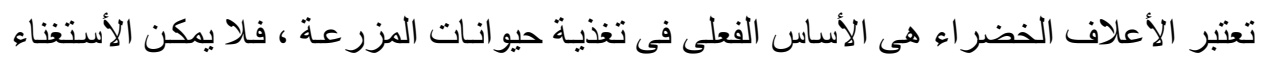

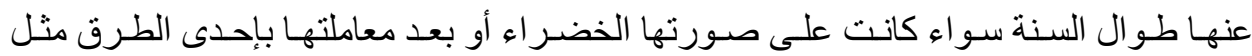

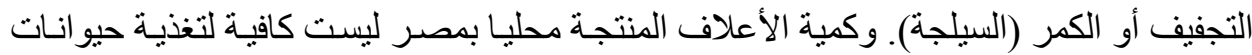

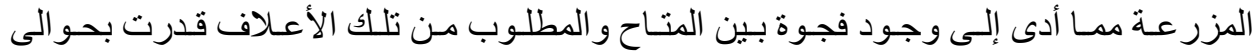

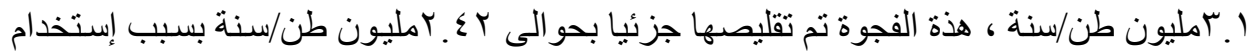

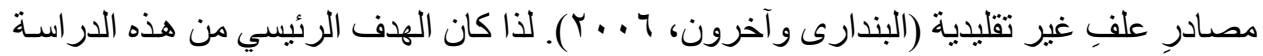

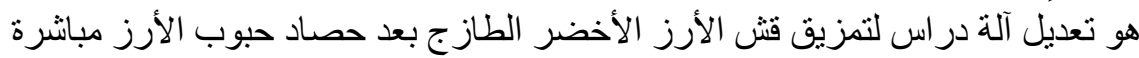

$$
\begin{aligned}
& \text { * باحث - معهد بحوث الهندسة الزراعية ـ الدقي - جيزة - مصر. } \\
& \text { ** أستاذـ معهد بحوث الأنتاج الحيوانى ـ الاقي - جيزة - مصر. }
\end{aligned}
$$




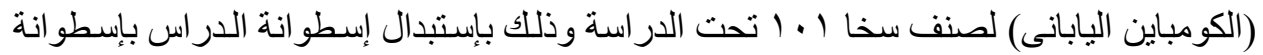

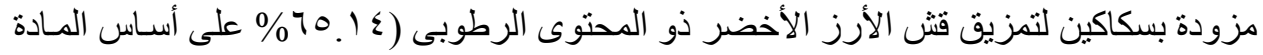

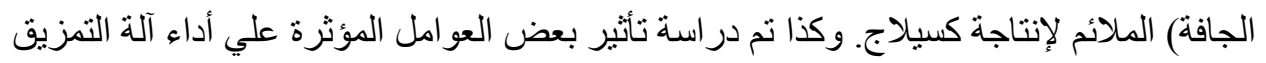

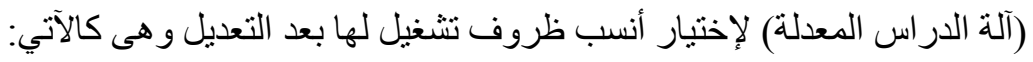

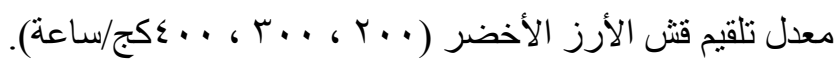

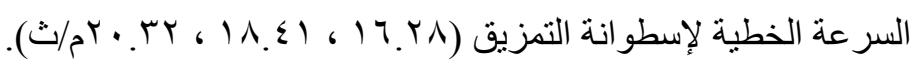
نسبة الخلوص للصدر بين الخلفى والأمامى (سTس. . ، 0. . ، . . 1).

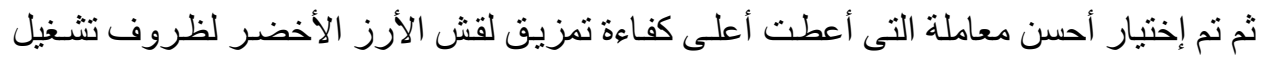

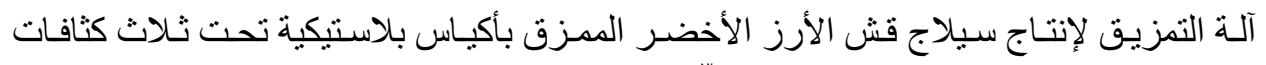

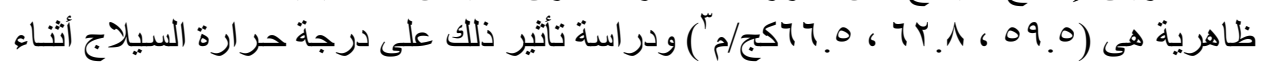

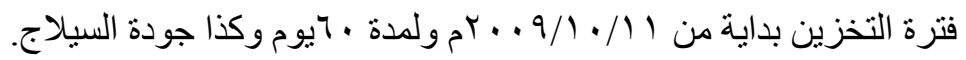
وقد أظهرت النتائج المتحصل عليها ما يلي:

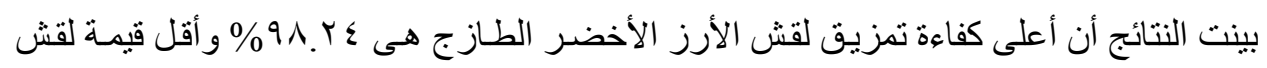

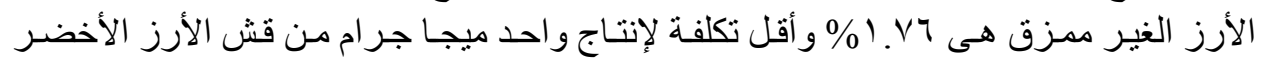

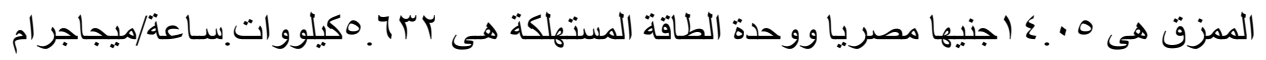

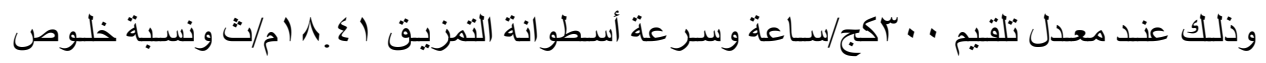

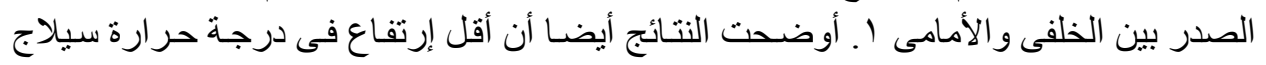

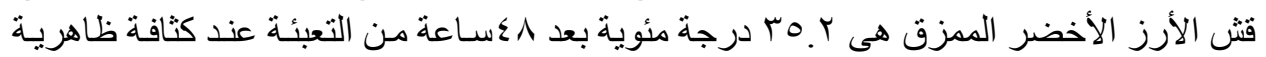

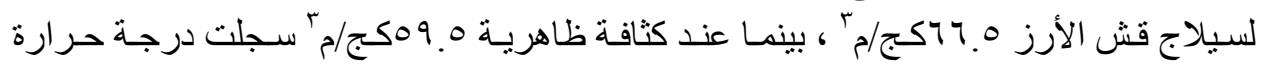

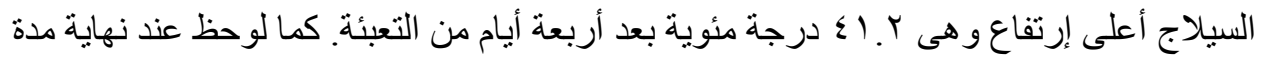

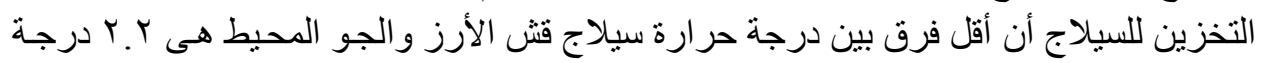

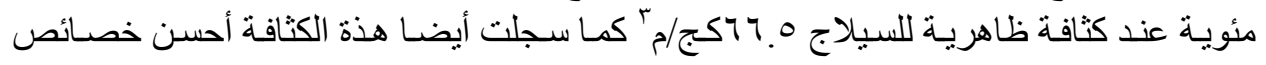

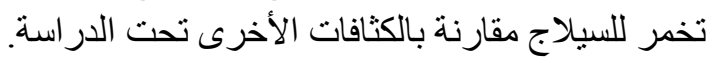

